MAREK JERZY UGLORZ, BIELSKO-BIAŁA

\title{
EKUMENICZNE ZNACZENIE TEOLOGII MARCINA LUTRA
}

\section{Zamiast wstępu pytanie o ekumeniczną teologię}

Czy chrześcijańska teologia może być nieekumeniczna? W moim przekonaniu współcześnie taką być nie może, w przeciwnym przypadku nie jest teologią w sensie ścisłym, a jedynie substytutem chrześcijańskiego słowa Boga, słowa do Boga, i słowa o Bogu, i to nawet nie naukowym, ponieważ każda dziedzina nauki jest cząstką holistycznego opisu rzeczywistości, służy więc temu, co jest uniwersalne. Ponadto dodajmy, że to chrześcijańskie słowo, biorąc pod uwagę hebrajskie źródło, ma powstawać między sercem a nerkami, zaś ze względu na grecki kontekst powinno angażować głowę. A jeśli teologia ma rodzić się między sercem a nerkami, więc musi też odczuwać i współodczuwać, służyć zaufaniu i miłości, i także w tym sensie spełniać ekumeniczną rolę.

To ludzka hybris, przejaw niezwykle aroganckiej ludzkiej natury, poddanej mocy grzechu, uczyniła z teologii - czyli z dynamicznego słowa teofanii, dziejącej się na różnorodnych płaszczyznach ludzkiej egzystencji, także w całej złożoności ludzkiej osoby, o czym przekonuje nas współczesna psychologia, i wreszcie nadającej nowe znaczenia złożonym relacjom między ludźmi - narzędzie przemocy, zawłaszczającej myślenie, sumienie i prawo do oceny ludzkich dziejów. Tymczasem prawdziwa teologia chrześcijańska jest ekumeniczna przynajmniej z dwóch powodów:

Po pierwsze, dlatego, że jej podstawowym źródłem jest słowo Boga, jednego i jedynego, jedynie Żywego. Jeśli jest jeden Bóg, Jahwe, który historycznie objawił się w dziejach Izraela i osobie Jezusa z Galilei, a poza Nim Boga nie ma, wobec tego, jak w ogóle można pomyśleć i uprawiać teologię nieekumeniczną, to jest taką, 
która nie integruje ludzi w doświadczeniu Słowa, które stało się ciałem, aby wszyscy byli jedno?

Po drugie, dlatego, że jej adresatem jest człowiek, czyli istota, która w Bogu rozpoznaje Ojca wszystkich ludzi, zamieszkujących jedną planetę, która została stworzona na mieszkanie, czyli dom, dla wszystkich bez wyjątku. Greckie słowo oikos, oznaczające „dom”, jest tymczasem źródłosłowem dla naszego pojęcia „ekumenizm”. Więcej nawet, jest nim także dla dwóch innych, równie ważnych pojęć, które wespół z ekumenizmem integrują ludzki świat, teologicznie nadając mu sens chrześcijańskiego domu, w którym wszyscy doświadczają błogosławionej i zbawiającej obecności Boga w Jezusie Chrystusie. Te pojęcia to: „ekonomia” oraz „ekologia”. Nieekumeniczna teologia podważa więc ideę wspólnego domu i nie ma najmniejszego prawa do formułowania wypowiedzi domagających się pogłębionego rozumienia problemów ekonomicznych bądź ekologicznych. Służy wówczas jedynie arbitralnym rozstrzygnięciom o jakości oraz intensywności doświadczenia Bożej obecności przez jednostkę bądź wspólnotę, która na skutek grzechu zatraciła pokorną pamięć o ziemi, jako domu wszystkich ludzi.

Dziś, ponad wszelką wątpliwość, wiemy, że teologia, która siebie nie pojmuje ani pod względem podmiotowym, ani przedmiotowym jako ekumeniczną, nie jest teologią chrześcijańską, bo nie rodzi się z Chrystusowego Ducha. Jako wyraz ludzkiej hybris, zamierzającej zawłaszczyć przestrzeń ziemi na użytek jednej wspólnoty i na jej wyłączną chwałę, podobnie jak w biblijnym opowiadaniu o budowniczych wieży Babel, zamiast czcić Boga, taka teologia służy ludzkiej czci i dezintegruje ludzką wspólnotę do takiego stopnia, że porozumienie staje się niemożliwe, a cywilizacja przeżywa poważny kryzys, jak to było w Europie na skutek niektórych działań reformacyjnych i kontrreformacyjnych, czego najtragiczniejszym przejawem była wojna trzydziestoletnia.

Byłoby naiwnością sądzić, że współczesna teologia zyskała ekumeniczną samoświadomość i przestała służyć introwertycznemu doświadczeniu religijnemu wyłącznie dzięki ekumenicznemu otwarciu, którego byliśmy świadkami w XX w. Sama teologia też 
bezustannie się rozwija, ulepsza swoją metodę i poszukuje nowych locus theologicus. Teologia ekumeniczna stała się możliwa przede wszystkim dzięki szybko rozwijającej się biblistyce. Pogłębione i precyzyjne badania tekstów biblijnych, zapoczątkowane wystąpieniem J. Ph. Gablera 30 marca 1787 r., w którym przedstawił podstawy do rozdzielenia teologii biblijnej od dogmatycznej, w tradycji ewangelickiej zwyczajowo mają być wolne od założeń dogmatycznych i wyznaniowych, oczywiście poza środowiskami fundamentalnymi, zaś w tradycji rzymskokatolickiej takimi stały się dzięki II Soborowi Watykańskiemu. Współczesna biblistyka jest w pełnym tego słowa znaczeniu teologią ekumeniczną.

Kolejnym katalizatorem zmian była i wciąż jest nowa hermeneutyka, która ewangelicyzmowi umożliwiła przemyślenie roli symbolu i jego związku ze słowem, a także napięcia, występującego między wydarzeniem a interpretacją, czyli słowem a tradycją, zaś katolicyzmowi uświadamia inne znaczenie wypowiedzi dogmatycznej, odpowiadające tradycyjnemu ujęciu ewangelickiemu, jako wypowiedzi o charakterze dynamicznym a nie statycznym, której celem jest nie tylko historyczny opis stanu wiary, ale przede wszystkim inspiracja do nowego przemyślenia stanu wiary przez kolejne pokolenia, co uwidacznia już sama nazwa. ${ }^{1}$

Dlatego jestem przekonany, że współcześnie nie można uprawiać teologii nieekumenicznej. Tak pod względem źródeł, z których teolog czerpie inspiracje do przemyśleń i tez, jak też przewidując ich skutki w otwartym i krytycznie słuchającym świecie, teolog musi wypowiadać się ekumenicznie, mając świadomość, że chociaż tworzy w duchu własnej tradycji teologicznej i duchowej, mimo wszystko służy nie tylko swojemu Kościołowi, ale wszystkim mieszkańcom jednego domu, którzy mają prawo do uniwersalnej wspólnoty ziemian (adamitów), mimo że Bożej obecności doświadczają na różne sposoby.

Mówiąc jeszcze inaczej, współczesna teologia nie powinna dłużej stawiać pytań w rodzaju: „Gdzie jest Bóg?”, ponieważ odpowiedzią

1 W luterańskiej teologii systematycznej rolę terminu „dogmat” przejął termin ,artykuł wiary”. 
najczęściej zawłaszcza przestrzeń egzystencji na potrzebę jednej wspólnoty religijnej, która identyfikuje się z miejscem przebywania Boga i rodzajem kultu, właściwym temu miejscu. Mamy wtedy do czynienia z teologią centralizującą kult i doświadczenie wiary, próbującą podporządkować wszystkich jednemu ośrodkowi religijnemu; teologią absolutnie nieekumeniczną. Współczesna teologia powinna raczej stawiać pytania w rodzaju: „W jaki sposób jest Bóg?” i uczyć się formułowania odpowiedzi, które wreszcie - po dwóch tysiącach lat - poważnie zaczną traktować słowa Jezusa z Galilei, skierowane do Samarytanki przy studni Jakuba: „Niewiasto, wierz mi, że nadchodzi godzina, kiedy ani na tej górze, ani w Jerozolimie nie będzie oddawali czci Ojcu. (...) lecz nadchodzi godzina i teraz jest, kiedy prawdziwi czciciele będą oddawali Ojcu cześć w duchu i w prawdzie" (J 4,21-23).

Pytanie o rodzaj Bożej obecności, i sposób jej doświadczania, w większym stopniu będzie służyło umacnianiu ekumenicznej wspólnoty ziemian. Współczesna teologia musi zatem przestać służyć cywilizacji technologicznej, zawłaszczającej przestrzeń, a koniecznie powinna zacząć tworzyć cywilizację ducha, ucząc ludzi życia w czasie, a także właściwego wykorzystywania czasu, jako daru łaski i zbawienia. Dzięki czemu będzie nie tylko teologią ekumeniczną, ale i ekologiczną, mającą też prawo do wypowiedzi o charakterze ekonomicznym.

Takiej teologii ekumenicznej - jak ją pojmuję - nie odnajdziemy oczywiście ani u Lutra, ani u Augustyna czy Tomasza z Akwinu. Współczesnych kryteriów teologicznych nie wolno stosować do teologicznej refleksji naszych przodków, którym ekumenizm był tak daleki, jak współczesny kryzys ekologiczny czy kapitalistyczna ekonomia. Mimo wszystko pytanie o ekumeniczne znaczenie teologii Marcina Lutra dla współczesnej myśli teologicznej jest poprawne i potrzebne, dlatego trzeba szukać ekumenicznych konsekwencji działalności reformatora $\mathrm{z}$ Witttenbergi. 


\section{Ekumeniczna rola ewangelickiego etosu pracy}

\section{Reformacyjne novum}

Wbrew obiegowym i nieprawdziwym opiniom XVI-wieczna reformacja nie rozpoczęła się na obrzeżach Kościoła i wiary, w świecie ideałów rodzącego się humanizmu. Swojej błyskawicznej ekspresji nie zawdzięcza też jedynie sprzyjającym warunkom społecznym i politycznym. Reformacja poczęła się może na kulturowym opłotku, $\mathrm{z}$ dala od wiodących centrów średniowiecznej Europy, gdzie nie pulsowało nawet życie Kościoła. Bez wątpienia poczęła się jednak w sercu zbawiennego wydarzenia, jakim jest chrześcijaństwo. W dodatku na styku dwóch charakterystycznych dla chrześcijaństwa przestrzeni religijnego i kulturowego doświadczenia, które nie wykluczają się, ale wyznaczają cywilizacyjny porządek Europy. Chodzi mianowicie o klasztor oraz uniwersytet. ${ }^{2}$

W ewangelickich kręgach przez długie wieki rozpowszechniony był pogląd, że reformacja uratowała Kościół przed całkowitym upadkiem i po wiekach pogłębiającej się ciemności przywróciła zachodniemu chrześcijaństwu światłość Ewangelii. W takiej optyce wszystko, co w wiekach średnich działo się na Zachodnie, nie zasługuje na uwagę, bo w żadnym wypadku nie wpłynęło na dzieło odnowy Kościoła. Dziś ten pogląd wśród teologów nie jest już powszechny, jednak wśród wiernych wciąż można spotkać się z jego przeróżnymi modyfikacjami.

Odwrotnie sądzono w Kościele rzymskokatolickim. I chociaż od dobrych stu lat trafiają się teolodzy, którzy nie odmawiają reformacji i Kościołom ewangelickim prawa do współtworzenia i współuczestnictwa w głównym nurcie chrześcijańskiej historii, rzesze katolików są przekonane, że to właśnie reformacja sięgnęła dna, a Kościoły, powstałe w jej wyniku, do dziś nie podniosły się z ciemności.

2 G. D u b y, Czasy katedr, Warszawa 2002³; R. S e n n e t t, Ciało i kamień. Człowiek i miasto w cywilizacji Zachodu, Gdańsk 1996. 
Zarówno pierwszy, jak i drugi pogląd, nie dopuszcza myśli, że między średniowiecznym Kościołem a reformacją może istnieć teologiczny i duchowy związek. Nie prosta kontynuacja, ale coś w rodzaju inspiracji bądź rozwoju pewnych idei, które pojawiły się wcześniej, jednak nie zostały dostrzeżone i właściwie rozwinięte. W teologicznej refleksji M. Lutra, i jego współpracowników, niewątpliwie pojawiły się nowe wątki i praktyczne rozwiązania, których próżno szukać wcześniej. Mimo wszystko dalsze podtrzymywanie obu poglądów nie sprzyja spokojnej i merytorycznej ocenie stanu Kościoła w dniu wystąpienia wittenberskiego reformatora oraz samej reformacji. A to oznacza, że reformacja, która zrodziła się w przestrzeni wzajemnego oddziaływania klasztoru i uniwersytetu, być może także w sferze teologicznej, jednak na pewno pod względem duchowym nie jest zjawiskiem nowym. Jej duchowość jest konsekwencją dającego się zauważyć na chrześcijańskim Zachodzie procesu, który w sferze duchowej ustala nowe priorytety.

O jakim procesie mowa i w związku z tym, co ciekawego da się powiedzieć o duchowości średniowiecznego Zachodu? Zacząć trzeba od reguły Benedykta z Nursji (VI w.), na której oparła swój ustrój większość wczesnośredniowiecznych klasztorów. Chociaż Benedykt nie lekceważył pracy, akcent położył na modlitwie i doświadczeniu religijnym, które współcześnie chętnie określamy mianem kontemplacji. Najbardziej pouczające jest to, co później stało się z regułą Benedykta. Gdy nastała epoka cystersów, co stało się na przełomie XI w. i XII w., którzy za przykładem opactwa w Citeaux w Burgundii, oparli swoje wspólnoty na odnowionej regule tego największego mnicha chrześcijańskiego Zachodu, nastąpiło zauważalne przesunięcie akcentu z kontemplacji na pracę. Gdyby średniowieczna rzeczywistość była inna, dziś nie moglibyśmy utrzymywać, że cystersom zawdzięczamy wykarczowanie europejskich borów, osuszenie mokradeł i założenie licznych opactw, które w wielu wypadkach stały się zalążkiem późniejszych miast.

Różnice między regułą benedyktyńską a cysterską przemawiają za poglądem, że w średniowiecznej duchowości doszło do zainicjowania pewnego procesu. Po fazie wstępnej, w której klasztor wyznaczał 
środek chrześcijańskiej przestrzeni i był odpowiedzialny za duchowy ideał chrześcijanina, nastąpił ruch na zewnątrz. Klasztor zaczął tworzyć pierwsze związki ze światem. Równolegle powstawały nowe ideały duchowe.

Kolejnym objawem nawiązywania przez średniowieczny klasztor związków ze światem są powstałe na początku w XIII w. zakony dominikanów i franciszkanów. Pierwszy zajął się teologią na powstających uniwersytetach, drugi amboną i nauczaniem prostego ludu. Jesteśmy więc świadkami kolejnego etapu wychodzenia klasztornej wspólnoty na zewnątrz. Jednak tym razem mamy do czynienia $z$ transpozycją klasztornych ideałów nie na pracę, ale na ewangelizację i katechizację.

Jeśli dostrzegamy ów proces i jest dla nas oczywiste, że chrześcijańska duchowość nie mogła na długo dać się zamknąć w klasztornych murach, to znaczy sublimować pod względem eremickim, nie powinniśmy dziwić się duchowym wzorcom reformacji. Nie ulega wątpliwości, że powstały pod wpływem nowego odczytania biblijnych tekstów, zwłaszcza świadectwa apostoła Pawła o usprawiedliwieniu $\mathrm{z}$ łaski przez wiarę. Jednak trudno wyobrazić sobie ewangelicki ideał mnicha, żyjącego w świecie i realizującego Boże powołanie codzienną pracą i założeniem rodziny, w której pełni obowiązki nauczyciela oraz duchowego przewodnika, nie traktując poważnie kierunków rozwoju duchowości średniowiecznego Kościoła.

Pod względem historycznym zasadnicze rysy duchowości luterańskiej i ewangelickiego etosu pracy są konsekwencją i kontynuacją procesu coraz szerszego otwierania klasztornej furty. Wpierw mnisi zajęli się pracą wewnątrz murów, wyznaczających świętą przestrzeń, potem wyszli na zewnątrz, aby ujarzmić wrogą przestrzeń europejskich równin. Nie minęło dużo czasu, a zajęli się nauczaniem i ewangelizacją ludu, który od pięciu wieków pozostawał poza murami ogrodu życia. Czy wobec tych faktów można się dziwić, że po upływie kolejnych trzech wieków, augustiański eremita, doktor teologii z prowincjonalnego uniwersytetu w Wittenberdze, ks. Marcin Luter, odważył się opuścić klasztorne mury i poślubić byłą mniszkę, Katarzynę von Bora? Transpozycja mniszego ideału na pracę, potem na 
ewangelizację i katechizację oraz zadzierzgnięcie ścisłych związków z średniowiecznym uniwersytetem, mającym coraz większe znaczenie cywilizacyjne, zakończyła się powstaniem duchowości, która czyni klasztor z przestrzeni i czasu swojego bycia w świecie, zaś w przestrzeni publicznej i społecznej wykrystalizowaniem się etosu pracy.

Chociaż reformator z Wittenbergi posługiwał się kategoriami bliskimi mistyce, jednak zgoła inaczej rozumiał relację między Bogiem a człowiekiem. Można powiedzieć, że na bazie usprawiedliwienia biernego rozwinął całościową koncepcję duchowości darowanej. Ponieważ Bóg w Chrystusie uczynił wszystko, człowiekowi w sferze zbawienia już nic nie pozostaje do zrobienia, nawet w życiu wewnętrznym. Owszem, dzięki Bożemu zbawieniu w Chrystusie, dochodzi do powstania prawdziwej komunii dziękczynienia i wdzięczności. Tylko ten, kto nauczył się nie pokładać zaufania w sobie i swoich możliwościach, może zrozumieć dar Boga w Chrystusie i doznać radości wiary. Z miłości do Boga i ufnej wiary w Chrystusa, rodzą się czyny, które mają wartość przed Bożym obliczem.

Odkąd ludzie zostali zwolnieni z troski o własne zbawienie, bardziej zainteresowali się światem. Człowiek, aby rzeczywiście mógł okazał się pobożnym, nie musiał opuszczać świata i uciekać przed konsekwencjami życia w świecie, wkraczając w klasztorne mury. Odtąd codzienność życia w świecie stała się najwłaściwszym chrześcijaństwu sposobem realizowania mniszego ideału. To znaczy, że Boga nie tylko można, ale wręcz należy czcić w codziennym życiu, zyskując w ten sposób pogłębioną samoświadomość. Praca rolnika i rzemieślnika nie jest mniej pobożna od modlitw mnicha. Dla duchowości oznaczało to zwrócenie się w stronę wielu nowych aspektów życia, a przede wszystkim, że odtąd duchowość nie jest zarezerwowana wyłącznie dla elit, ale zajmuje należne jej miejsce w samym środku przestrzeni i czasu ludzkiej egzystencji. Między innymi dlatego od czasów reformacji datuje się przyśpieszony rozwój handlu i nauki, a w XIX w. także przemysłu.

Ludzie mogli odtąd służyć Bogu swoim świeckim powołaniem i doświadczać błogosławionych skutków bycia pobożnym człowiekiem w każdej dziedzinie życia społecznego. Ewangelicka duchowość 
nie jest umiejscowiona między niebem a ziemią, a przynajmniej w wyizolowanej przestrzeni klasztornych murów, ale stała się formą doświadczania Bożej obecności w każdej chwili życia. Powołanie do pracy, każdej pożytecznej pracy, stało się jednocześnie powołaniem do życia mniszego, co prawda w szerszym, ale za to znacznie pogłębionym znaczeniu.

Jednym ze skutków luterańskiej reformacji, jak powiedzieliśmy wcześniej, było przeniesienie ośrodka chrześcijańskiego życia z klasztoru na plac, do warsztatu rzemieślniczego, do szkolnej ławy, czyli przyznanie codziennemu życiu w świecie prawa do bycia życiem pobożnym. Chrześcijanin uformowany w luterańskim duchu jest głęboko zakorzeniony w świecie i społeczeństwie, za które wobec Boga bierze odpowiedzialność. Ewangelicka duchowości jest więc duchowością profetyczną a nie apokaliptyczną, egoistyczną. Jej najbardziej właściwą formą wyrażania się jest droga od sacrum przestrzeni i czasu do świętości międzyludzkich relacji, które nie są autonomiczne, ale mocno osadzone w osobie Chrystusa. W tym nowym kontekście jawi się też typowa duchowość ewangelickiej rodziny, której obowiązkiem jest nie tylko religijne wychowanie dzieci i młodzieży. Bardzo ważnym składnikiem wychowawczych działań ewangelickiej rodziny jest zadbanie o wykształcenie dzieci i wdrożenie ich do pracy, aby nie wiodły leniwego życia, ale swoją pracą służyły innym, na podobieństwo Jezusa Chrystusa.

Ewangelicki etos pracy a współczesna ekonomia

Coraz więcej ludzi, nie wytrzymujących ekonomicznego i technologicznego wyścigu, powiada, że świat zwariował. Świat nie zwariował, bo nie mógł. To raczej chrześcijaństwo w kręgu oddziaływania cywilizacji euro-atlantyckiej nie miało dość sił albo odwagi i determinacji, by w odpowiednim czasie wypromować miłość jako zasadę cywilizacyjnego rozwoju i główny nerw międzyludzkich relacji i struktur. W efekcie oświecenie na krótko wypromowało wolny rozum, jako podstawową strukturę społeczną i ekonomiczną, 
a wraz z nim pojawiła się w kosmosie jednostka, dokonująca wyborów etycznych. Jednak czas wiktorii rozumu nie trwał długo, ponieważ niemal natychmiast pojawiła się groźna mutacja, czyli mit o jednostce, która jest zdolna dokonywać efektywnych wyborów, to jest wykalkulowanych, niepodległych uczuciom i namiętnościom, skutkujących najkorzystniejszymi decyzjami ekonomicznymi; mit o doskonałym homo economicus.

Ekonomia budowała swoje dotychczasowe modele, zakładając istnienie takiego ekonomicznego indywiduum, jednak w pespektywie ostatniego kryzysu światowego trzeba zadać pytanie, czy homo economicus przypomina prawdziwego człowieka? Bo jeśli nie, to jakbyśmy modele ekonomiczne, stworzone w celu opisania społecznych i kulturowych zachowań neandertalczyka, który przecież dawno wymarł, chcieli stosować w świecie ponowoczesnym. Koncepcja homo economicus była do tej pory skomplikowaną metodą uzasadniania ludzkich zachowań ekonomicznych. Jeśli dla przykładu konsument wybiera w sklepie tańszy produkt, ekonomiści powiadają, że maksymalizuje użyteczność. A jeśli Jezus z Galilei radzi oddać suknię temu, który chce nam zabrać płaszcz (Łk 6,29), czy też posługuje się zasadą maksymalizacji użyteczności, tyle że w perspektywie eschatologicznej?

Od pojawienia się pierwszej fali światowego kryzysu jesteśmy na szczęście świadkami upadku mitu homo economicus. W efekcie nawet ekonomiści ze światową renomą nie ukrywają dziś dość oczywistej prawdy, a mianowicie, że nie można dłużej rozwijać ekonomii, nie uwzględniając prawdy o człowieku, jako istocie zanurzonej w wewnętrzny świat uczuć oraz realizującej zewnętrzne relacje ze społeczeństwem z wykorzystaniem emocji i doświadczeń, zaś wyjście z kryzysu będzie możliwe pod dwoma warunkami. Pierwszym jest odbudowanie wzajemnego zaufania przez instytucje, społeczności i jednostki. A zaufanie jest przecież jednym z podstawowych i najszlachetniejszych uczuć, które jest w dodatku nierozerwalnie połączone z innym wielkim uczuciem, jakim jest miłość. Drugim warunkiem jest nadanie pracy nowego sensu, z uwzględnieniem relacji 
oraz interakcji, zachodzących między jednostką a społeczeństwem, aby nie tworzyć kolejnego modelu dla ekonomicznego egoisty.

Powinniśmy cieszyć się z kryzysu, ponieważ to, co wydawało się niemożliwe, nieoczekiwanie zaczęło się dziać. Okazuje się, że arogancki wobec klasycznych wzorców myślenia pośrednik finansowy, który w XX w. był wielokrotnie bardziej ceniony aniżeli wychowawca w zakładzie karnym, nauczyciel w szkole i filozof $\mathrm{z}$ teologiem do spółki, nagle traci wiarygodność i musi wytłumaczyć się, dlaczego, studiując ekonomię, nie poznał też podstaw antropologii filozoficznej i teologicznej.

Dzięki kryzysowi ekonomia przypomniała sobie o kulturowym, religijnym, emocjonalnym i jeszcze kilku innych kontekstach egzystencji człowieka. Równania matematyczne same z siebie nie mają sensu. Sens pojawia się dopiero przez odniesienie do kontekstu. Zwłaszcza wówczas, gdy ekonomiści zastanawiają się nad tym, jak działa społeczeństwo, muszą mieć świadomość tego wszystkiego, z czego się ono wyłoniło i jakich treści używa, tworząc się współcześnie, a przecież między innymi są to kulturowe i religijne archetypy, charakterystyczne dla każdego ludu historie, z właściwą dla nich hermeneutyką interpretacji, filozofia, obraz Boga i fundująca się na nim samoświadomość jednostki.

Mając wiedzę o stanie światowej gospodarki i świadomość tworzenia się nowego paradygmatu ekonomicznego, ryzykuję stwierdzenie, że ewangelicki etos pracy jest odpowiednią i ekumeniczną propozycją dla współczesnej ekonomii. Oczywiście w jego klasycznej, reformacyjnej formie, jako efekt procesu kulturowego, który daje się zauważyć w teologii i duchowości chrześcijańskiego Zachodu począwszy od VI w., a nie wynaturzonego tzw. duchem kapitalizmu, w którym zatracił się podstawowy charakter pracy jako służby Bogu w etycznym działaniu wobec człowieka. Użyteczny tym bardziej, że ma niepowtarzalną i do tej pory nigdy nie wykorzystaną zdolność integrowania wielu przejawów ludzkiej aktywności religijnej i świeckiej.

Co przez to należy rozumieć? Po pierwsze, w XXI w. zdecydowanie lepiej, aniżeli u progu rewolucji przemysłowej a potem rewolucji 
informatycznej, zdajemy sobie sprawę z tego, że najważniejsze wymiary ludzkiego świata trzeba integrować intelektualnym wysiłkiem i praktycznym działaniem. Ludzki świat, czyli z grecka oikos, jest złożonym systemem przyrodniczym i cywilizacyjnym, w którym na jakość życia i poczucie szczęścia mają wpływ trzy dziedziny ludzkiej aktywności, do tej pory rozwijane najczęściej niezależnie od siebie, które tymczasem są ze sobą powiązane nie tylko semantycznie, ale przede wszystkim ze względu na skutki, a mianowicie ekonomia, ekologia i ekumenizm.

Ekologia, ekonomia, ekumenizm - to wciąż ta sama mądrość życia, tyle tylko, że jedna zajmuje się środowiskiem naturalnym, druga materialnością ludzkiego bytu, a trzecia jego wymiarami społecznymi i duchowymi. Postuluję, by ekonomię właśnie tak pojmować, integralnie z pozostałymi elementami. Zresztą podobnie należałoby traktować ekologię i ekumenizm. Gdy jedno z tych pojęć zostaje oderwane od pozostałych i w wybiórczy sposób potraktowane, przynosi człowiekowi przekleństwo i zadaje śmierć.

Pod tym względem ewangelicki etos pracy jest po pierwsze modelem godnym zaufania, ponieważ sprawdzonym w etnicznym i kulturowym tyglu ludów środkowej Europy, a po drugie umożliwia sformułowanie nowego paradygmatu ekonomicznego, z wykorzystaniem pogłębionego rozumienia ludzkich zachowań religijnych i społecznych. Wizją pracy, jako służby, którą człowiek nadaje sens swojej egzystencji, ewangelicki etos pracy wykorzystuje religijno-kulturowy potencjał jednostki, aktywując wzajemną miłość i zdolność człowieka do budowania relacji, łagodząc niszczycielską siłę ludzkiej hybris, której aktywność w krótszej bądź dłuższej perspektywie czasowej zawsze prowadzi do społecznej katastrofy, cierpienia i śmierci.

\section{Teolog z Wittenbergi ekumenicznym nauczycielem}

W 1970 r., podczas V Ogólnego Zgromadzenia Światowej Federacji Luterańskiej, kard. Johannes Willebrands nazwał Lutra wspólnym nauczycielem. Należy przypuszczać, że myślał o chrześcijaństwie zachodnim, tak czy inaczej wypowiedział bardzo odważną myśl. Od 
tamtego wystąpienia minęło ponad 40 lat, a sformułowanie Willebrandsa nie doczekało się specjalnego uznania ani rozwinięcia. Co prawda tak po ewangelickiej, jak po katolickiej stronie, pojawiło się kilka specjalistycznych studiów, ${ }^{3}$ dających pogłębiony historycznie obraz Lutra i jego teologii, dzięki którym rozumiemy Lutra w kontekście działalności XVI-wiecznego Kościoła, jako uczestnika teologicznej dyskusji, mimo wszystko ani luteranie nie zdecydowali się oddać prawa własności do interpretowania Lutra, pastoralistom i kaznodziejom katolickim, ani oni sami nie czują potrzeby upomnienia się o nie. Ekumeniczne znaczenie teologii Lutra pozostaje przedmiotem zainteresowania wąskiego grona teologów i takich dokumentów międzykościelnych, jak Wspólna Deklaracja o Usprawiedliwieniu.

3 P. A 1 th a u s, Die Theologie Martin Luthers, Güthersloh 1963; t e n ż e, Die Theologie Maritn Luthers nach seinen Predigten, Göttingen 1988; O. B a y e r, Martin Luthers Theologie, Tübingen 2003; A.B e u t e 1, Martin Luther, München 1991; H. B a u m e i s e r, Martin Luthers Kreuzesthelogie, Paderborn 1995; A. B r a nd e n burg, Gericht und Evangelium. Zur Worttheologie in Lutherserster Psalmenvorlesung, Paderborn 1960; t e n ż e, Martin Luther, t. I-III, Stuttgart 1981-1987; Ch. B. B u r a n d t, Der eine Glaube zu allen Zeiten. Luthers Sicht der geschichte aufgrund der Operationes in Psalmos 1519-1521, Hamburg 1995; G. E b e l in g, Luther. Einfuhrung in seinen Denken, Tübingen 1981; R. F r i e d e n t h a 1, Luther: Sein Leben und seine Zeit, München 1967; F. G o g a r t e n, Luthers Theologie, Tübingen 1967; A. H a m e 1, Der junge Luther und Augustin. Ihre Beziehungen in der Rechtfertigungslehre nach Luthers ersten Vorlesungen 1509-1518 untersucht, t. I-II, Gütersloh 1934/1935; W. v o n L o e w e n i c h, Luthers theologia cruces, München 1929; t e n ż e , Martin Luther; Der Mann und das Werk, München 1981; B. L o h s e, Martin Luther. Eine Einführung in sein Leben und sein Werk, München 1981; H. L u t z, Das Ringen um Deutsche Einheit und kirchliche Erneuerung, Berlin 1983; P. M e in hold, Luther heute. Wirken und Theologie Martin Luthers, des Reformators der Kirche, in ihrer Bedeutung für die Gegenwart, Berlin-Hamburg 1967; K. H. Mü h 1 e n, Nos extra nos. Luthers Theologie zwischen Mystik und Scholastik, Tübingen 1972; H. O b e r m a n, Werden und Wertung der Reformation. Vom Wegestreit zum Glaubenskampf, Tübingen 1977; D. O 1 i v i e r, Der Fall Luther. Geschichte einer Verurteilung 1517-1521, Stuttgart 1972; J. P e 1 i k a n, Luther the Expositor, w: Luther's Works, St. Louis 1959; R. S c h w a r z, Fides, spes und caritas beim jungen Luther, Berlin 1962; S. S t r e i f f, „Novis linguis loqui”. Martin Luthers Disputation über Joh 1,14 „,verbum caro factum est” aus dem Jahre 1539, Göttingen 1993. 
Czy wobec tego Luter może być wspólnym nauczycielem chrześcijańskiego Zachodu, a mówiąc inaczej, nauczycielem ekumenicznym? Oczywiście tak. Pokażę to na przykładzie dwóch zagadnień, zajmujących reformatora $\mathrm{z}$ Wittenbergi, które ze względu na dzisiejszy stan badań jego teologii oraz rozwój biblistyki i dogmatyki, w stosunku do XVI-wiecznego stanu w pomimo przekonaniu noszą charakter ekumeniczny, tak uwzględniając przedmiot myśli, jak też jej skutki praktyczne.

Niewolna wola, czyli reinterpretacja grzechu pierworodnego

Zagadkowej i dla wielu wciąż mrocznej nauki Lutra o niewolnej woli nie wolno traktować w oderwaniu od antropologicznego pytania o wolność oraz grzech, czyli odpowiedzialność za zło. Dopiero wówczas staje się zrozumiała i nabiera ekumenicznego znaczenia, chociaż do niedawna wydawało się to absolutnie niemożliwe.

Na pytanie, czy człowiek jest istotą wolną totalnie, zdolną samemu decydować o wyborze życia i śmierci, teolog z Wittenbergi jednoznacznie zaprzecza, ucząc, że człowiek, zniewolony miłością Boga, która czyni go wolnym do wielbienia Boga, a przez to powiększania własnego człowieczeństwa, służby i budowania właściwych relacji wspólnotowych, może być albo wolnym paradoksalnie w Bogu, albo wolnym tragicznie, będąc ubezwłasnowolnionym przez własne „nie”, swój wybór ciemności i śmierci. To oznacza, że człowiek jest prawdziwie wolny wówczas, gdy traci wolność w Chrystusie (wolność paradoksalna), a traci wolność wtedy, gdy oddala się od Boga i próbuje zachować autonomię woli i działania (wolność tragiczna).

Luter nie zna człowieka wolnego w sensie ścisłym, jako wolnego podmiotu dziejów, zdolnego do konstytuowania samego siebie pomiędzy dobrem a złem, światłością a ciemnością, Bogiem a grzechem. Kto próbuje afirmować samego siebie w oderwaniu od Boga, traci wolność, czyniąc grzech, który odwróceniem się od Boga i niewiarą. Kto zaś w Chrystusie zostaje uwolniony z mocy grzechu, staje się niewolnikiem miłości, aby całym życiem mógł czcić zbawiającego Boga. Dlatego chrześcijańską egzystencję Luter może opisać zadziwiającą 
aporią: „Chrześcijanin jest całkowicie wolnym panem wszystkich rzeczy, nikomu nie podległym. Chrześcijanin jest najuleglejszym sługą wszystkich rzeczy i wszystkim podległy".

Prawdziwa wolność zawsze jest wolnością dwubiegunową; wolnością od rzeczywistej niewoli, której biblijnym archetypem jest Egipt, ku czemuś, w chrześcijaństwie ku służbie, czyli ku jakiejś nowej formie zniewolenia, tylko że ta nowa rzeczywistość nie jest już niewolą w dotychczasowym sensie. Realizuje się na zupełnie innym poziomie rozpoznania własnej osobowości oraz relacji z samym sobą, bliźnim, wspólnotą i stworzeniem. Można powiedzieć, że to nowe zniewolenie jest zyskiwaniem samego siebie w relacji do Boga, jest odkrywaniem nowej formy własnej tożsamości. W jej wyniku przemienia się ludzka duchowość, także eros, ekonomia bycia oraz to wszystko, co współcześnie wyrażamy pojęciem ekologii.

Dopiero teraz widać, że Lutrowej nauki o niewolnej woli nie wolno traktować jako wypowiedzi antropologicznej w sensie ścisłym. Jej cel jest inny. Jest mianowicie jedną z kolejnych konceptualizacji zła, w pewnym sensie Lutrowym rozwinięciem nauki o grzechu pierworodnym, która przezwycięża skandaliczną koncepcję odpowiedzialności zbiorowej, chociaż jednocześnie zachowuje realistyczną prawdę o ponadbiologicznej i ponadhistorycznej jedności rodzaju ludzkiego, ujawniającą się w świadomości winy wszystkich ludzi a uzewnętrzniającą się wyznawaniem grzechów przez „ludzkość, zgromadzoną przed Bogiem". ${ }^{4}$

W czasach bezpośrednio poprzedzających wystąpienie Marcina Lutra właściwie nie dyskutowano nad naturą grzechu pierworodnego. W średniowieczu grzech pierworodny uważano za temat domagający się jedynie refleksji abstrakcyjnej, tymczasem dla Lutra stał się on czymś realnym, doświadczalnym w życiu. ${ }^{5}$ Dlatego jego rozważania nabrały m.in. charakteru egzystencjalnego. Prócz tego opisał grzech pierworodny (peccatum originale) oraz wynikającą z tego sytuację

\footnotetext{
4 P. R i c o e u r, Symbolika zła, Warszawa 1986, s. 82.

5 J. B y c z k ow s k i, Próby reinterpretacji dekretu Soboru Trydenckiego o grzechu pierworodnym, RTK 2/1970, s. 79.
} 
człowieka z perspektywy teocentrycznej i chrystocentrycznej, jako całkowicie wypaczony stosunek człowieka do Boga.

Korzeń grzechu pierworodnego ma swą istotną siedzibę w wyższych władzach człowieka, przede wszystkim zaś w woli. Natura człowieka wyraża się w woli. Był to pogląd całej franciszkańskiej szkoły teologicznej, w której zawsze dominował augustynizm z jego woluntaryzmem. Luter jednak nie przyjmował średniowiecznego poglądu na temat wolnej woli (liberum arbitrium), lecz pisał o niewolnej woli (servum arbitrium). ${ }^{6} \mathrm{~W}$ wyniku upadku w grzech wola została zdeprawowana i jako taka stanowi - według Lutra - właśnie o istocie grzechu pierworodnego, który wyraża się w korzystaniu ze zwróconej wolności przeciwko Bogu. Całkowita grzeszność jest przyczyną braku wolnej woli. Ponieważ wszyscy są niewolnikami grzechu - pisał Luter w swoim komentarzu do Listu do Rzymian z okresu późniejszego - przeto po upadku w grzech pierworodny wszyscy mają wolę zniewoloną.

Grzech pierworodny pochodzi z zewnątrz, ale nie jest dziełem Bożym. Bóg nie jest przyczyną grzechu, lecz diabeł i nasza wolność. ${ }^{8}$ Człowiek więc znajduje się między Bogiem a szatanem. Po upadku Adama, którego grzech jest dziedziczny, człowiek jest zwrócony przeciwko Bogu. Taka postawa wyraża się konkretnie w braku bojaźni Bożej, zaufania i miłości do Boga, czyli w samozamknięciu się człowieka, zwróceniu się ku sobie, w poleganiu wyłącznie na sobie oraz szukaniu zbawienia w stworzeniach i własnych uczynkach. Człowiek nie może dzięki siłom przyrodzonym miłować Boga i poznać Go. ${ }^{9}$ Nie jest to tylko skłonność do złego lub zły zamysł. Jest to radykalna postawa, która jako swoistego rodzaju stan habitualny aktualizuje się w każdym grzechu uczynkowym.

6 M. L u t e r, De servo arbitrio, Berlin 1983 (wyd. pol. O niewolnej woli, tłum. W. N i e m c z y k, Warszawa 1977).

7 WA 56,369 .

8 Tamże, 39 I, s. 374: „Deus non est autor, quia ipswe non iusit, sed prohibuit magis, ne peccamus. Sed diabolus et voluntas nostra sund causa peccati”.

9 Artykuły szmalkaldzkie III, I, 2.5 (KWKL, s. 345n.). 
W przekonaniu Lutra grzech pierworodny polega na całkowitym braku prawości i zupełnej niemożności działania władz ciała i duszy oraz całego wewnętrznego i zewnętrznego człowieka. Jest skłonnością do złego. ${ }^{10}$ Skoro człowiek jest całkowicie popsuty, przeto jego działanie - jeśli człowiek nie działa z pomocą Boga - nie jest dobrem. Człowiek wówczas myśli wyłącznie o swojej chwale i dlatego grzeszy. ${ }^{11}$ Wówczas nawet dobry uczynek - twierdzi Luter za Augustynem - nacechowany jest piętnem grzechu.

W polemice z Erazmem z Rotterdamu, komentując 1Mż 6,3.5 Luter pisał: „Nie mówi «zamysł» lub «skłonność do złego», lecz że człowiek przez całe życie w ogóle nie co innego wymyśla i myśli jak tylko zło; istota jego złości opisana jest tak, iż nie czyni inaczej i nie może czynić inaczej, skoro jest zła. Ani bowiem, jak zaświadcza Chrystus, złe drzewo nie może przynosić innych owoców jak tylko złe (Mt 7, 17)". ${ }^{12}$ Człowiek nie jest więc grzesznikiem dlatego, że grzeszy, ale grzeszy, ponieważ jest grzesznikiem. W tym grzesznym stanie już się człowiek rodzi, co wcale, według Marcina Lutra, nie pomniejsza jego winy. Człowiek ,z konieczności grzeszy i błądzi, dopóki przez Ducha Bożego nie zostanie naprowadzony na drogę dobra". ${ }^{13}$

Grzech pierworodny jest rzeczywistą winą i może być ona usunięta jedynie przez chrzest. Chrzest nie jest tylko znakiem przyjęcia do społeczności chrześcijańskiej, ale znakiem uśmiercenia starego Adama i powstania nowego człowieka. Charakterystyczna jest w tym względzie wypowiedź Lutra z Dużego Katechizmu, w której także scharakteryzował skutki grzechu pierworodnego: „W końcu należy też wiedzieć, jakie jest znaczenie chrztu i dlaczego Bóg kazał stosować taki zewnętrzny znak i dopełnić obrzędu przy sakramencie, przez który zostajemy najpierw przyjęci do społeczności chrześcijańskiej.

10 ,...sed prorsus priuato vniuerse rectitudinis et potentie omnium virium tam corporis quam anime ac totius hominis interioris et exteioris. Isuper et pronita ipsaad malum, nausea ad bonum" - WA 56,312.

11 Tamże, 56, s. 289.

12 M. L u t e r, De servo arbitrio, s. 244.

13 Tamże, s. 201. 
Tym aktem, czyli obrzędem, jest zanurzenie w wodzie, która nas zakrywa, i wydobycie z niej. Owe dwie części, zanurzenie w wodzie i wydobycie z niej, oznaczając moc i skutek chrztu, który polega na uśmierceniu starego Adama, następnie zaś na powstaniu nowego człowieka. Jedno i drugie powinno się dziać w nas przez całe życie, gdyż chrześcijańskie życie nie jest niczym innym, jak codziennym chrztem raz rozpoczętym i ciągle trwającym. Trzeba to bowiem czynić ustawicznie: zawsze wymiatać to, co należy do starego Adama, aby mogło powstawać to, co należy do nowego. Lecz cóż to jest ten stary człowiek? Jest to człowiek, który nam jest przyrodzony od Adama: zagniewany, nienawidzący, zazdrosny, nieczysty, chciwy, leniwy, wyniosły, niewierzący, napełniony wszystkimi przywarami i nie mający $\mathrm{z}$ natury nic dobrego w sobie. Skoro więc weszliśmy do królestwa Chrystusowego, musi codziennie ubywać tamtych rzeczy, abyśmy im dłużej żyjemy, stawali się tym łagodniejsi, cierpliwsi, cichsi, porzucający coraz bardziej skąpstwo, nienawiść, zazdrość, pychę". ${ }^{14}$

Peccatum originale - jak widać wyraźnie - jest ściśle powiązane $\mathrm{z}$ naturą człowieka, ale tym samym nie jest bynajmniej jeszcze pozbawione momentu personalnego. ${ }^{15}$ Moment ten został wyraźnie zaakcentowany przez Lutra w jego rozumieniu chrztu, który chociaż jest aktem jednorazowym, to jednak musi się codziennie przez pokutę, żal za grzechy i wiarę w moc krzyża Chrystusa aktualizować. Chrzest bowiem nie usuwa grzechu pierworodnego, lecz winę za ten grzech, a więc partycypowanie w grzechu pierwszego człowieka. Luter na pytanie: „Co więc znaczy takie chrzczenie wodą?” odpowiada: „Znaczy to, że stary Adam w nas przez codzienny żal i pokutę ma być utopiony i umrzeć ze wszystkimi grzechami i złymi pożądliwościami, natomiast ma codziennie wyłaniać się i powstawać nowy człowiek, który by w sprawiedliwości i czystości żył wiecznie przed Bogiem". ${ }^{16}$ Nie jest to jednak dzieło człowieka, lecz własne dzieło Boga. Łaskawy

14 KWKL, s. 120.

15 P. J a c o b s, Sünde und Schuld (dogmengeschichtlich), Evangelisches Kirchenlexikon III, Göttingen 1962, s. 1225n.

16 KWKL, s. 49. 
i wszechmogący Bóg wybawia człowieka spod władzy szatana i od grzechu przez Jezusa Chrystusa. ${ }^{17}$

Poglądy Lutra na temat grzechu pierworodnego są w wielu punktach identyczne z poglądami biskupa Hippony, Augustyna, ${ }^{18}$ a nawet Tomasza w Akwinu, w wielu jednak szczegółach znacznie radykalniejsze. Sytuację człowieka po upadku w grzech pojmował jako beznadziejną i zaradzić mogła jej tylko zbawcza ofiara Chrystusa na krzyżu. Na skutek grzechu pierworodnego człowiek nic nie może sam uczynić dla siebie, aby poprawić swoją sytuację. ${ }^{19}$ Jedynym ratunkiem jest Chrystus.

Egzystencjalna prawda symbolu zła, jakim jest grzech pierworodny, ujawnia tajemniczy aspekt zła, polegający na tym, że chociaż każdy człowiek sam zapoczątkowuje zło, to jednocześnie odnajduje jego obecność w sobie, poza sobą i przed sobą. Wszelka świadomość, biorąca odpowiedzialność za grzech, stwierdza, że zło już istnieje, a każdy następny człowiek uaktualnia je i kontynuuje. ${ }^{20}$ Symbol grzechu pierworodnego rozwiązuje więc sprzeczność między wspólnotowym charakterem zła całej ludzkości, a osobistą odpowiedzialnością każdego grzesznika za uczynione zło. I chociaż zbieżność woli i niewoli w jednej i tej samej egzystencji wciąż jest nie do pomyślenia, jednak rekapitulując wszystkie wcześniejsze symbole zła, wraz z grzechem pierworodnym, niewolna wola jest być może jak dotąd jedynym symbolem, wyznaczającym kierunek dalszej refleksji nad naturą zła, rozwiązującym sprzeczność jednoczesnego doświadczania niewoli i wolności oraz bycia poddanym mocy grzechu przy jednoczesnej pewności bycia usprawiedliwionym w Chrystusie. Tym bardziej że współczesna socjologia i psychologia coraz odważniej mówią o micie wolnej woli, który w najbliższym czasie definitywnie

17 Zob. szerzej: P. A 1 t h a u s, Die Theologie Martin Luthers, s. 144nn.

18 Na temat związków teologii Lutra z teologią Augustyna zob. H.-U. D e 1 i u s, Augustin als Quelle Luthers, Berlin 1984.

19 J. Gro s s, Entwicklungsgeschichte des Erbsündendogmas, t. IV, München 1972, s. 75

20 P. R i c o e u r, Podług nadziei, Warszawa 1991, s. 214. 
obalą wyniki badań nad zachowaniami jednostki, poddanej działaniu i presji wspólnoty, a także motywów, jakimi kieruje się człowiek, podejmujący decyzje.

\section{Teologia krzyża, czyli sapientia practica}

Franciszkanin, o. Antoni Nowak, otwierając XVI Tydzień Duchowości, powiedział: „Cierpienie jest nieodzownym wymiarem ludzkiego życia. Kto nie akceptuje krzyża, ten nie akceptuje Chrystusa, ten nie akceptuje życia. Życie bez krzyża jest utopią, teologia zaś bez krzyża - oszustwem". ${ }^{21}$ Te słowa, miłe dla luterskich uszu, nie padły podczas ekumenicznego spotkania z grzeczności. One wypowiadane są w prostocie serca i autentycznie przez każdego, kto w swoim życiu poważnie potraktował Chrystusowe: „Pójdź za mną" i z powagą odczytuje biblijne poselstwo o Bogu i człowieku, życiu i śmierci. Luteranizm nie rości sobie prawa wyłączności do teologii krzyża. Gdyby tak było, wówczas byłby bardzo nieekumeniczny, ponieważ tym samym prawo do interpretowania Ewangelii rezerwowałby wyłącznie dla siebie.

W rzeczy samej, bez względu na to, jak bywa nazywana, teologia krzyża jest hermeneutycznym kluczem, otwierającym Bożą skarbnicę objawienia. Historia dogmatów dostarcza dowodów na to, że teologia krzyża jest wspólnym dziedzictwem różnych tradycji teologicznych. Marcin Luter nie stworzył teologii krzyża, ale ją zreinterpretował i usystematyzował. Zasady swojego myślenia o krzyżu opisał pierwszy raz $\mathrm{w}$ tezach, przedstawionych braciom zakonnym podczas konwentu zakonu w Heidelbergu, w kwietniu $1518 \mathrm{r}$.

Rodowód tej refleksji bez wątpienia jest biblijny. Uzasadnieniem niech będą cztery nowotestamentowe teksty. Pierwszy pochodzi z Ewangelii Łukasza: „I powiedział do wszystkich: Jeśli kto chce pójść za mną, niechaj się zaprze samego siebie i bierze krzyż swój na siebie codziennie, i naśladuje mnie. Kto bowiem chce zachować

${ }^{21}$ A. J. N ow a k, Wprowadzenie, w: t e n ż e (red.), Cierpienie i śmierć, Lublin 1992, s. 16. 
duszę swoją, straci ją, kto zaś straci duszę swoją dla mnie, ten ją zachowa" (Łk 9,23n.). Warto zauważyć, że już w ustach Jezusa z Galilei zarysował się typowy dla rozwiniętej teologii krzyża, paradoksalny język aporii: strata = zysk; śmierć = życie.

Zwróćmy też uwagę na świadectwo pierwszego teologa krzyża, w pełni zasługującego na to miano, czyli ap. Pawła: „Zewsząd uciskani, nie jesteśmy jednak pognębieni, zakłopotani, ale nie zrozpaczeni, Prześladowani, ale nie opuszczeni, powaleni, ale nie pokonani, Zawsze śmierć Jezusa na ciele swoim noszący, aby i życie Jezusa na ciele naszym się ujawniło" (2Kor 4,8-10), zaś w Liście do Galacjan znajdujemy świadectwo: „Co zaś do mnie, niech mnie Bóg uchowa, abym miał się chlubić z czego innego, jak tylko z krzyża Pana naszego, Jezusa Chrystusa, przez którego dla mnie świat jest ukrzyżowany, a ja dla świata" (Ga 6,14). I na koniec sztandarowy tekst z 1 Listu do Koryntian: „Skoro bowiem świat przez mądrość swoją nie poznał Boga w jego Bożej mądrości, przeto upodobało się Bogu zbawić wierzących przez głupie zwiastowanie. Podczas gdy Żydzi znaków się domagają, a Grecy mądrości poszukują. My zwiastujemy Chrystusa ukrzyżowanego, dla Żydów wprawdzie zgorszenie, a dla pogan głupstwo, Natomiast dla powołanych - i Żydów, i Greków, zwiastujemy Chrystusa, który jest mocą Bożą i mądrością Bożą" (1Kor 1,21-24).

Nie są to jedyne teksty, ale ograniczmy się do nich, aby uznać ekumeniczne znaczenie teologii krzyża, która przede wszystkim dlatego należy do uniwersalnego dziedzictwa wszystkich chrześcijan, ponieważ legitymuje się biblijną genezą. Dlatego teologia krzyża nie potrzebuje ani dodatkowego ekumenicznego uzasadnienia, ani obrony, ponieważ wprost wyrasta z tego gruntu, w którym ekumenizm szuka dla siebie miejsca i skąd czerpie impulsy.

Jednak poza argumentem zewnętrznym, w samej teologii krzyża można odnaleźć argumenty wewnętrzne, wynikające z jej podstawowych twierdzeń. Nie ma co ukrywać, że większość tzw. problemów ekumenicznych udałoby się szybko rozwiązać, gdybyśmy posługiwali się jednym językiem teologicznym. Teologia krzyża stwarza taką szansę. W jej przestrzeni semantycznej i semiotycznej mogą ze sobą 
porozumiewać się różne tradycje teologiczne i duchowe. Ta ekumeniczna otwartość i giętkość teologii crucis musi jednak gdzieś mieć swoje źródło. Odnajdujemy je w tym, co można nazwać genetycznym kodem teologii krzyża, a więc w jej podstawowych zasadach, które od czasów Lutra nie uległy zmianie, ani też nikt ich nie podważył.

Jednak o atrakcyjności i ekumenicznej aktualności teologii krzyża stanowi coś szczególnego. To mianowicie, że jest nie tylko wiedzą teoretyczną, aczkolwiek jest przecież wiedzą i umiejętnością, lecz przede wszystkim opisuje egzystencjalne doświadczenie człowieka z krzyżem. Jest próbą opowiedzenia życia pod krzyżem i pomimo krzyża; jest zwiastowaniem Boga, ukrywającego się w hańbie i poniżeniu, aby pod osłoną krzyża człowiek mógł doświadczyć uśmiechniętego Ojca. Dlatego teologia krzyża przede wszystkim ma charakter sapiencjalny. Jako życiowa mądrość ma zastosowanie w praktycznym życiu.

Można powiedzieć, że jest hermeneutyczną zasadą teologii, pretendującej do miana biblijnej, i jednocześnie hermeneutyczną zasadą egzystencjalnego doświadczenia żywego Boga, pomimo krzyża i śmierci.

\section{Zamiast zakończenia pytanie o odnowę Kościoła}

W przeszłości bardzo często zarzucano Lutrowi, że działał ze złych pobudek i doprowadził do powstania Kościoła przeciwko Kościołowi. W cechach charakteru, kompleksach, złym wpływie ojca, niedouczeniu i jeszcze kilku innych negatywnych motywach doszukiwano się genezy kacerskiej działalności Lutra. Rozpowszechniona była też opinia, że reformacja nie była prawdziwą odnowy Kościoła, ponieważ wówczas reformatorzy nie dopuściliby do rozłamu w zachodnim chrześcijaństwie, ale typową rewolucją, noszącą znamiona społeczne i polityczne. Naprawa Kościoła była zatem jedynie pretekstem, o czym miałby przekonywać polityczny protektorat elektora saskiego, dzięki któremu Luter przeżył, a reformacja zyskała rozmach.

Dziś na szczęście takie poglądy zostały przezwyciężone i przechodzą do historii, za to coraz powszechniejszym staje się przekonanie, 
że tak naprawdę reformacja zaczęła się w sali wykładowej, to znaczy, że genetycznie jest owocem teologicznej pracy ks. dr. M. Lutra, a dokładniej rzecz nazywając, nowej hermeneutyki, którą zaczął się posługiwać. Myślę, że studiując biografię reformatora, i doceniając fakt, że, jego zdaniem, fundamentalnym artykułem wiary jest usprawiedliwienie z łaski, jesteśmy świadkami podobnego wydarzenia, jakie miało miejsce w życiu apostoła Pawła w drodze do Damaszku, czyli Bożego powołania, które przed teologiem odkrywa prawdziwy sens Ewangelii, jakby teologicznego olśnienia, w świetle którego wszystko inne zaczyna jawić się jako mało istotne.

To tłumaczy, dlaczego subiektywnie Luter był przekonany o obiektywnej wartości swojego teologicznego odkrycia i nie ustępował swoim przeciwnikom z rzymskiej kurii, ani późniejszym z obozu reformatorskiego. Tego typu przeżycie, jak podpowiada egzegeza tekstu, opisującego spotkanie wywyższonego Chrystusa z Pawłem, a także jego osobistych wypowiedzi, którymi w swoich listach komentuje tamto wydarzenia, nie jest tylko nawróceniem, ale przede wszystkim aktem powołania. Teolog Paweł bądź teolog Luter czuli się powołani do zwiastowania Ewangelii, czyli do służenia Chrystusowi, dlatego w ich działaniu ujawnia się niezwykły dynamizm, który uwolniony przez procesy społeczne i polityczne, rozwijał się z każdym nowym słowem i czynem, doprowadzając do powstania nowej jakości., która jednych gorszyła, innych fascynowała.

Interpretując postać Lutra w takim świetle, można wskazać na jeszcze jeden, ekumeniczny walor jego działalności, związany z kondycją europejskiego chrześcijaństwa, która - co tu dużo mówić - nie jest najlepsza. Od kilku dziesięcioleci rozważamy, w jaki sposób naprawić chrześcijaństwo Starego Świata i jakbyśmy nie zauważali najważniejszego czynnika reformacyjnego, pojmowanego w sensie ekumenicznym i uniwersalnym, czyli katolickim, a mianowicie, że każdy życiodajny impuls i odnowa religijna, co bardzo dobrze widać też na przykładzie religii Izraela, inicjuje teologia. Nieszczęściem naszych czasów jest brak zaufania do ludzi ideowych, którzy pragną inspirować i wskazywać nowe cele, ponieważ największym 
zaufaniem cieszą się tzw. praktycy, którzy najczęściej uwikłani są w dotychczasowe schematy i utrwalone struktury.

Jeśli chcemy odnowionego, europejskiego chrześcijaństwa, musimy wspierać teologię. Nawet niekoniecznie teologów w sensie personalnym, ale po prostu teologię, jako formę epifanii żywego Chrystusa, by na podobieństwo morskiej fali z głębin ludzkiej nadziei i modlitwy na powierzchnię dziejów wyniosła nową formę europejskiego chrześcijaństwa, gotową do dialogu ze współczesnym światem i odpowiednią do działalności misyjnej wśród ludzi, których nowym środowiskiem życia jest informatyczna sieć. Nie należy przypuszczać, by tę rolę mogła spełniać teologia konfesyjna w sensie ścisłym, ponieważ współczesne pokolenie dzięki sieci jest uniwersalne i zunifikowane. Dlatego musi to być teologia w pełnym tego słowa znaczeniu ekumeniczna, integrująca różne tradycje duchowe, przede wszystkim ze względu na stosowane przez siebie metody. Teologia otwarta, pozbawiona lęków, potrafiąca wychylić głowę poza obowiązujący schemat poznania i wnioskowania, aby zrozumieć współczesny świat i zainspirować do działania na Bożą chwałę.

W tym sensie postać ekumenicznego nauczyciela z Wittenbergi może pełnić rolę zachęcającą oraz inspirującą. 